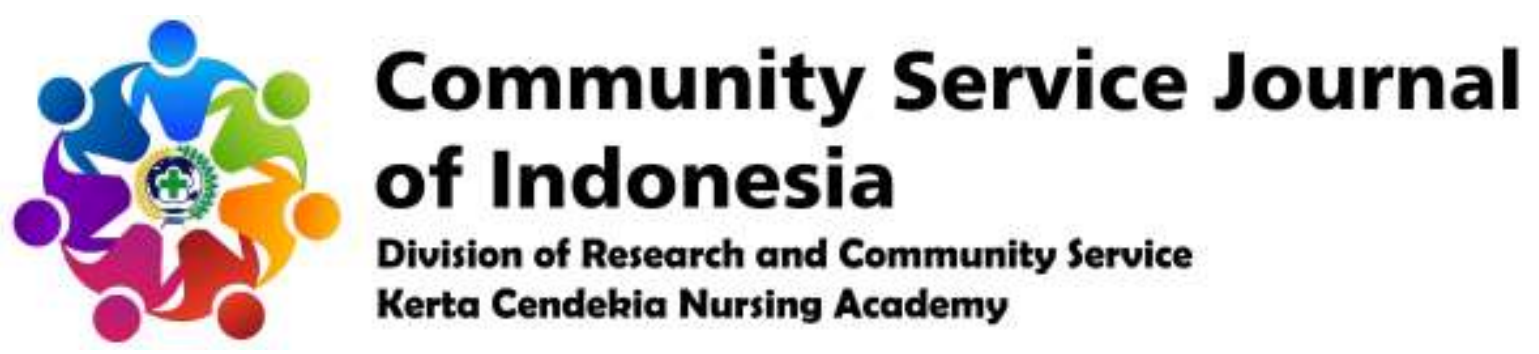

https://ejournal-kertacendekia.id/index.php/csji/index

Community Service Journal of Indonesia 3 (1) (2021): 1-3

Doi: https://doi.org/10.36720/csji.v3i1.283

\title{
IMPROVING OF SOCIETY'S KNOWLEDGE ABOUT PREVENTION OF CORONARY HEART DISEASE FROM AN EARLY AGE
}
Meli Diana ${ }^{1 *}$, Dini Prastyo Wijayanti ${ }^{1}$, Dimas Hadi Prayoga ${ }^{1}$, Nurhanifah Mawarni ${ }^{2}$, Kiki Widyasari ${ }^{2}$

\author{
${ }^{1}$ Lecturer of Health Polytechnic of Kerta Cendekia, Sidoarjo \\ ${ }^{2}$ Students of Health Polytechnic of Kerta Cendekia, Sidoarjo \\ * Correspondence \\ Meli Diana \\ Health Polytechnic of Kerta Cendekia \\ Lingkar Timur Road, Rangkah Kidul Village, Sidoarjo Sub-District, \\ Sidoarjo Regency, East Java Province, Indonesia - 61234 \\ Email: melidiana159357@gmail.com
}

\begin{abstract}
Community Service activities organized by Health Polytechnic of Kerta Cendekia, Sidoarjo in collaboration with Baitul Mal Hidayatulloh (BMH) Sidoarjo held a Health Talk Show which was broadcast live streaming on the POS DAI SIDOARJO channel with the theme "Prevention of Coronary Heart Disease Early". The Health Talk Show was held on Sunday, April 11, 2021 at the BMH office in Pondok Mutiara Sidoarjo. This activity was carried out in a team consisting of three lecturers of Health Polytechnic of Kerta Cendekia, Sidoarjo, 2 students, and a team from BMH Sidoarjo. The activity was arranged by the team for two weeks, starting from determining the theme of the activity, the form of the activity, the timing of the activity, and the socialization of the activity through social media. This activity was witnessed by the wider community, especially in the Sidoarjo area. As a form of evaluation, this community service activity ran smoothly, seen 250 viewers on the YouTube channel, viewers were enthusiastic about participating in the activity by asking questions via live chat.
\end{abstract}

Keywords: Coronary heart disease, early age, knowledge, health prevention.

(C) 2021 The Authors. Community Service Journal of Indonesia Published by Institute for Research and Community Service, Health Polytechnic of Kerta Cendekia, Sidoarjo

This is an Open Access Article distributed under the terms of the Creative Commons Attribution 4.0 International License which permits unrestricted non-commercial use, distribution, and reproduction in any medium, provided the original work is properly cited.

E-ISSN

2684-7884

P-ISSN

2774-4027 


\section{INTRODUCTION}

Coronary heart disease is a disease caused by decreased blood flow and oxygen to the heart organ. Heart disease also called the silent killer because it often shows no symptoms in the early stages of the disease. Coronary heart disease is a deadly disease, especially when there is a delay in providing help. Some of the risk factors that can trigger coronary heart disease include hypertension, hypercholesterolemia, diabetes mellitus, genetic factors, obesity, unhealthy diet, and a lifestyle that is not enough to exercise. WHO data in 2016 stated that more than 17.9 million people worldwide died from heart and blood vessel disease. The results of Riskesdas in 2018 show that $1.5 \%$ or 15 out of 1,000 people in Indonesia suffer from coronary heart disease.

At the time of the attack, the sufferer will feel chest pain like burning or crushed and spread to the neck, back. Patient safety when having a heart attack depends on the initial handling of the golden time, which is in the first 20 minutes when the attack occurs. Family or people around the sufferer must immediately seek medical help within the first 5 minutes. The role of nurses is very much needed in this case, especially in providing education to sufferers, families, and even the wider community about heart disease and early management of heart attacks. With this health education, it is hoped that the community will be able to provide early aid to people with cardiac arrest so that the patient's chance of surviving death increases.

\section{OBJECTIVES}

\section{General Purpose}

After 60 minutes of health education, it is hoped that the community will be able to understand heart disease and its management.

\section{Special Purpose}

After 60 minutes of health education, it is hoped that the community will be able to:

1. Identify the etiology of coronary heart disease.

2. Identify sign and symptom of coronary heart disease.

3. Identify the prevention of coronary heart disease.

4. Identify the implementation of coronary heart disease.

\section{PLAN OF ACTION}

\section{Strategy Plan}

The strategy plan implemented, including:

1. Coordinate with the team from Baitul Mal Hidayatulloh (BMH) Sidoarjo to carry out community service activities in the form of providing health education to the community.

2. Determine the time contract with $\mathrm{BMH}$ team and determine the form of activity.

3. Providing health education to the community at large.

\section{Implementation}

Actions taken in the implementation of these activities, including:

1. Prepare the place and all equipment needed for the implementation of health talk show.

2. Delivering material about the management of coronary heart disease from an early age.

\section{Setting}

This health talk show was held in Baitul Mal hidayatullah (BMH) Office in 
Pondok Mutiara Sidoarjo on April 11, 2021.

Target

Target in this health talk show event is community at large especially in Sidoarjo area.

\section{RESULTS AND DISCUSSION}

Health talk show that has theme "Prevention of Coronary Heart Disease from an Early Age" took place on April 11, 2021 which lasted for two hours starting at 9.00 to 11.00 WIB. Activities carried out according to plan that has been set before. This activity was attended by 250 viewers who overall seemed enthusiastic in the process of delivering the material of health education. This was indicated by the questions asked by viewer via live chat. In delivering materials, the speakers use language that easily understood by the public. The media used in this health talk show include laptop, powerpoints, speakers, sound, camera, LCD, and Youtube.

\section{CONCLUSION}

Knowledge improvement of prevention of coronary heart disease can prevent an incident of heart disease sufferers.

\section{REFERENCES}

Joyce, M. Black. (2014). Keperawatan Medikal Bedah. Jakarta: Salemba Medika.

Kementerian Kesehatan RI. (2018). Hasil Utama Riskesdas 2018. Retrieved from

https://kesmas.kemkes.go.id/assets/ upload/dir_519d41d8cd98f00/files/ Hasil-riskesdas-2018_1274.pdf
Nurarif, Amin Huda dan Kusuma, Hardhi. (2015) Apllikasi Asuhan Keperawatan Berdasarkan Diagnosa Media Nanda Nic-Noc. Jilid 1. Jogjakarta: Mediaction.

Udjianti, Wajan Juni. (2011). Keperawatan Kardiovaskuler. Jakarta: Salemba Medika. 